\title{
Conformational Ensembles: The Role of Neuropeptide Structures in Receptor Binding
}

\author{
Arthur S. Edison, Eduardo Espinoza, and Cherian Zachariah \\ Department of Biochemistry and Molecular Biology, Center for Structural Biology, University of Florida Brain Institute, and \\ National High Magnetic Field Laboratory, University of Florida, Gainesville, Florida 32610-0245
}

Conformational properties of several similar FMRFamide-like neuropeptides from mollusks were investigated by nuclear magnetic resonance (NMR) spectroscopy. It was found that amino acid substitutions in the $\mathrm{N}$-terminal variable regions of the peptides had dramatic effects on the populations of reverse turns in solution. The populations of turns, as measured by two independent NMR parameters, were found to be highly correlated $\left(r^{2}=0.93\right.$ and 0.82$)$ with $\mathrm{IC}_{50}$ values using receptor membrane preparations from Helix aspersa (Payza, 1987; Payza et al., 1989). These results suggest that the amount of turn in the free peptide can influence the receptor binding affinities of that peptide. On the basis of these observations, a model was developed in which only a single species from a conformational ensemble of an unbound peptide will bind to a particular receptor. Thus, the conformational ensemble reduces the effective concentration of a particular peptide with respect to a particular receptor.

Key words: FMRFamide-like peptides; NMR; structurefunction relations; conformational averaging; dynamics; threedimensional structure; reverse turn
Neuropeptides are a major source of neurochemical diversity, with functions as wide ranging, for example, as the modulation of the action of morphine and feeding behavior in mammals (Yang et al., 1985; Sakurai et al., 1998), the regulation of cardiac stimulation and pacemakers in mollusks (Payza, 1987; Simon et al., 1992), the stimulation or inhibition of oviduct contractions in locust (Wang et al., 1995a,b), and the modification of lobster pattern-generating circuits (Dickinson et al., 1990). Currently the largest, most widely distributed, and most diverse family of neuropeptides are the FMRFamide-like peptides (FLPs). FLPs are thought to be present in all animals (Greenberg and Price, 1992) and have amino acid sequence similarities to the "parent" peptide Phe-Met-Arg-Phe- $\mathrm{NH}_{2}$ (FMRFa), which was first discovered in the clam (Price and Greenberg, 1977).

FLPs, like other neuropeptides, are encoded by precursor proteins that are processed into mature peptides in the secretory pathway (Sossin et al., 1989). Some FLP precursor proteins produce multiple copies of the same peptide. The most dramatic example of multiple copies is from Aplysia, with 28 copies of FMRFamide and one copy of FLRFamide (Taussig and Scheller, 1986). Other precursor proteins encode several different FLPs, which tend to be longer than four amino acids and have common $\mathrm{C}$-terminal amino acid sequences and variable $\mathrm{N}$-terminal extensions. Large numbers of different FLPs are often present in a given animal. In nematodes, for example, Ascaris suum has at

Received March 26, 1999; revised May 7, 1999; accepted May 14, 1999.

These studies were supported by a grant from the Florida Affiliate of the American Heart Association (A.S.E.), the University of Florida Howard Hughes Medical Institute Pilot Studies program, and the University of Florida Brain Institute. Dan Plant and James Rocca, University of Florida Center for Structural Biology, provided important technical support. We thank Matt Carrigan and Professor Glen Cottrell for helpful and stimulating discussions and Professors Ben Dunn and Gerry Shaw for critically reading this manuscript. We give special thanks to the reviewer whose helpful comments led to a greatly improved manuscript.

Correspondence should be addressed to Dr. Arthur S. Edison, Department of Biochemistry and Molecular Biology, Center for Structural Biology, University of Florida Brain Institute, and National High Magnetic Field Laboratory, University of Florida, Gainesville, FL 32610-0245.

Copyright (C) 1999 Society for Neuroscience 0270-6474/99/196318-09\$05.00/0 least 20 different FLPs (Cowden et al., 1989; Cowden and Stretton, 1993, 1995; Edison et al., 1997), and Caenorhabditis elegans has 20 FLP genes (Rosoff et al., 1992; Wilson et al., 1994; Bargmann, 1998; Nelson et al., 1998; Chris Li, personal communication). If all of the $C$. elegans genes were expressed and fully processed, they would produce at least 56 different FLP peptides (Bargmann, 1998; Nelson et al., 1998).

The functional role of multiple diverse peptides is currently ambiguous. A deletion in C. elegans of a FLP precursor protein encoding for eight closely related peptides produces five distinct phenotypes (Nelson et al., 1998), but it is unknown whether individual peptides or a "bouquet" (Greenberg and Price, 1992) is responsible for the specific phenotypes. Substitutions of a single amino acid in an FLP from locust produces opposite G-proteinmediated responses (Wang et al., 1995a,b). Replacement of an aspartic acid by tyrosine lowers the receptor binding affinity of a molluscan FLP (Payza, 1987; Payza et al., 1989). In contrast, two similar FLPs have essentially identical effects on the crab stomatogastric ganglion (Weimann et al., 1993), and a group of six peptides from the same precursor protein in Ascaris (Edison et al., 1997) produces similar effects on Ascaris muscle (Davis and Stretton, 1996).

Here we report the conformational properties of individual peptides from a group of related FLPs from mollusks using nuclear magnetic resonance (NMR) spectroscopy and correlate the conformations with previously published receptor binding affinities (Payza, 1987; Payza et al., 1989). The organization of this paper is as follows. The technical NMR details are primarily limited to Materials and Methods. The Results section has four parts: NMR chemical shifts, NMR distance measurements, NMR $\mathrm{pH}$ dependence, and conformational models. Each NMR section has an introduction to the parameter with a description of its significance to the present study. The conformational model section presents a three-dimensional reverse turn structure that is most consistent with the NMR data and the known conformational properties of the amino acids comprising the peptides. The 
Discussion section begins with a summary of published results from receptor binding studies of the same set of peptides (Payza, 1987; Payza et al., 1989). We compare experimental conditions between the NMR and receptor binding experiments and show that the NMR conformations are directly correlated with binding affinities. The strong correlation leads to a model in which the active conformation of a peptide is only a fraction (up to 100\%) of the ensemble of conformations in solution. We end by discussing the biological significance of the conformational ensemble model and propose a set of experiments to further test its validity.

\section{MATERIALS AND METHODS}

Peptide synthesis. Peptides were synthesized by Alfred Chung (University of Florida Interdisciplinary Center for Biotechnology Research Protein Chemistry Core) at the $0.25 \mathrm{~mm}$ scale. After the synthesis of the conserved PFLRF-NH $\mathrm{H}_{2} \mathrm{C}$ terminus, the reaction was split for the individual synthesis of the different $\mathrm{N}$-terminal extensions. The peptides were made with a 432A Peptide Synthesizer (Applied Biosystems, Foster City, CA) using standard 4-(fluorenylmethyloxy)carbonyl chemistry and were cleaved from the solid support with trifluoroacetic acid in the presence of appropriate scavengers. The scavengers were extracted with t-butyl methyl ether, and the peptides were diluted with acetic acid and freezedried. When necessary, peptides were purified by HPLC. All peptides used for NMR were at least $95 \%$ pure, as estimated by analytical HPLC and mass spectrometry.

NMR spectroscopy. NMR data were collected at $600 \mathrm{MHz}$ using a Varian Unity 600 (Palo Alto, CA) at the University of Florida Center for Structural Biology. Approximately 1-5 mM samples were prepared with $90 \% \mathrm{H}_{2} \mathrm{O}, 10 \% \mathrm{D}_{2} \mathrm{O}$, and $0.3 \mathrm{~mm}$ 3-trimethylsilyl $\left(2,2,3,3-{ }^{2} \mathrm{H} 4\right)$ propionic acid for an internal chemical shift standard $(0.0 \mathrm{ppm})$. Unless otherwise indicated, the $\mathrm{pH}$ (uncorrected for $\mathrm{D}_{2} \mathrm{O}$ ) of each sample was adjusted to between 4.5 and 5.5. The temperature of the samples during data collection was $4^{\circ} \mathrm{C}$ unless indicated otherwise. For each peptide, we compared one-dimensional ${ }^{1} \mathrm{H}$ spectra between samples under the following conditions: high concentration peptide (1-5 mM) and low salt, high concentration peptide and $150 \mathrm{~mm} \mathrm{KCl}$, and a 10-fold dilution of the high concentration samples. None of the chemical shifts for any of the samples deviated by more than $\sim 0.02 \mathrm{ppm}$, showing the absence of any aggregation or salt effects.

Data were obtained with the transmitter centered on the $\mathrm{H}_{2} \mathrm{O}$ peak, which was reduced using presaturation or by excitation sculpting (Callihan et al., 1996). Proton spectral widths were between 10 and $13 \mathrm{ppm}$. One-dimensional data were generally collected with 16,384 points; twodimensional data were collected with 2048 or 4096 complex and 512 complex points in the acquisition and indirect dimensions, respectively.

One-dimensional ${ }^{1} \mathrm{H} \mathrm{pH}$ titrations were from $\mathrm{pH} 2$ to 5.6 at roughly 0.2 $\mathrm{pH}$ increments; the $\mathrm{pH}$ was adjusted by adding small volumes of concentrated $\mathrm{KOH}$ or $\mathrm{HCl}$ to the samples. Two-dimensional total correlation spectroscopy (Braunschweiler and Ernst, 1983) data were collected using an MLEV-17 mixing sequence applied for $60 \mathrm{msec}$ with an $8.8 \mathrm{kHz}$ radio frequency $(r f)$ field strength. Rotating Overhauser effect spectroscopy (ROESY) (Bothner-By et al., 1984) data were collected using continuous wave irradiation during the mixing time with an $r f$ field strength of 2.2-3 $\mathrm{kHz}$ and mixing times ranging from 150 to $300 \mathrm{msec}$. Quadrature detection in the indirect dimensions was achieved by the method of States and coworkers (1982).

Data were processed using the computer software NMRPipe (Delaglio et al., 1995) by first eliminating the residual water peak using spectral deconvolution followed by appodization with squared cosine functions, zero-filling to twice the original data size, Fourier transformation, and baseline correction. Data were sequentially assigned using standard methods (Wüthrich, 1986) using NMRview (Johnson and Blevins, 1994). Peak positions and intensities were determined using the automatic peak-picking routine in NMRview (Johnson and Blevins, 1994). Intensities were also checked by extracting one-dimensional slices through the peaks of interest.

\section{RESULTS}

NMR data were collected for the naturally occurring and modified peptides shown in Table 1 (Linacre et al., 1990; Price et al., 1990; Saunders et al., 1991; Lutz et al., 1992; Kellett et al., 1994). The series of peptides were chosen because of detailed binding $\overline{\text { Table 1. Peptides from this study and their measured NMR parameters }}$

$\begin{array}{lll}\text { Sequence }^{a} & I_{\mathrm{NN}} / I_{\alpha \mathrm{N}} \mathrm{F} 4-\mathrm{L} 5^{b} & \Delta \delta \mathrm{pH} \mathrm{F} 4(\mathrm{ppm})^{c} \\ \text { PFLRFa }^{d} & 0.0^{e} & \mathrm{NA}^{e} \\ \text { DPFLRFa }^{d} & 0.20^{f} & 0.128^{f} \\ \text { SDPFLRFa } & 0.48\left(4^{\circ} \mathrm{C}\right) & 0.33 \\ & 0.51\left(15^{\circ} \mathrm{C}\right) & \mathrm{ND} \\ & 1.58\left(26^{\circ} \mathrm{C}\right) & \mathrm{ND} \\ \text { GDPFLRFa } & 0.45\left(4^{\circ} \mathrm{C}\right) & 0.31 \\ & 0.72\left(15^{\circ} \mathrm{C}\right) & \mathrm{ND} \\ \text { NDPFLRFa }_{\text {pQDPFLRFa }} & 1.54\left(26^{\circ} \mathrm{C}\right) & \mathrm{ND} \\ \text { GYPFLRFa }^{d} & 0.24 & 0.33 \\ \text { pQYPFLRFa }^{d} & 0.28 & 0.35 \\ & 0.0 & \mathrm{NA} \\ \text { NA, Not } & 0.0 & \mathrm{NA}\end{array}$

NA, Not applicable (no titrating group); ND, not done.

${ }^{a}$ One-letter amino acid code with "pQ" = pyroglutamic acid and with "a" $=\mathrm{NH}_{2}$. ${ }^{b}$ Ratio of intensities of amide-to-amide $\left(I_{\mathrm{NN}}\right)$ and $\alpha$-to-amide $\left(I_{\alpha \mathrm{N}}\right)$ ROESY cross peaks between F4 and L5.

${ }^{c}$ Magnitude of the shift $(\Delta)$ in chemical shift $(\delta)$ of the amide proton of F4 as a function of $\mathrm{pH}$. The values represent the shift at highest $\mathrm{pH}$ minus the shift at lowest $\mathrm{pH}$.

${ }^{d}$ Not naturally occurring.

${ }^{e}$ Data are for F2 and L3.

${ }^{f}$ Data are for F3 and L4.

studies that revealed large differences in receptor binding affinities as a function of amino acid sequence (Payza, 1987; Payza et al., 1989). We used standard NMR methods to assign each resonance (peak) in the NMR spectrum to a particular atom in the peptide (Wüthrich, 1986). From the peak assignments, we obtained structural information from the positions of the peaks (chemical shifts), the $\mathrm{pH}$ dependence of the peaks, and interactions between atoms closer than $5 \AA$ in space.

Short linear peptides can be very flexible and often are completely averaged in solution. However, many examples can be cited in which short peptides have high populations of turns or helices (Dyson et al., 1988a,b; Mayo et al., 1991; Miick et al., 1992; Yao et al., 1994; Millhauser et al., 1996; Yeagle et al., 1997). It must be stressed that all of the NMR data shown below represent populations of averaged structures (Jardetzky, 1980; Bradley et al., 1990; Džakula et al., 1992). However, the population averaging varies in the series of peptides in this study from approximately zero to $80 \%$ turn.

\section{Chemical shifts}

Chemical shifts are extremely sensitive probes of molecular conformation. Despite recent advances in empirical (Wishart and Sykes, 1994) and theoretical (Oldfield, 1995) understanding of chemical shifts in proteins, conformational averaging and interactions with solvents currently prevent a quantitative use of chemical shifts in small peptides. Each atom in each amino acid has a characteristic and known random coil chemical shift value when the amino acid is completely random and without structure (Wishart and Sykes, 1994). Useful qualitative information can be gleaned from groups of similar peptides by comparing their chemical shifts with each other and with random coil values (Wishart and Sykes, 1994).

Figure 1 shows differences between random coil values of the amide $\left(\mathrm{H}^{\mathrm{N}}\right)$ and $\alpha\left(\mathrm{H}^{\alpha}\right)$ proton chemical shifts of the conserved PFLRF-NH $\mathrm{H}_{2}$ region of representative peptides from Table 1. The histograms of Figure 1 provide a "fingerprint" of the overall 

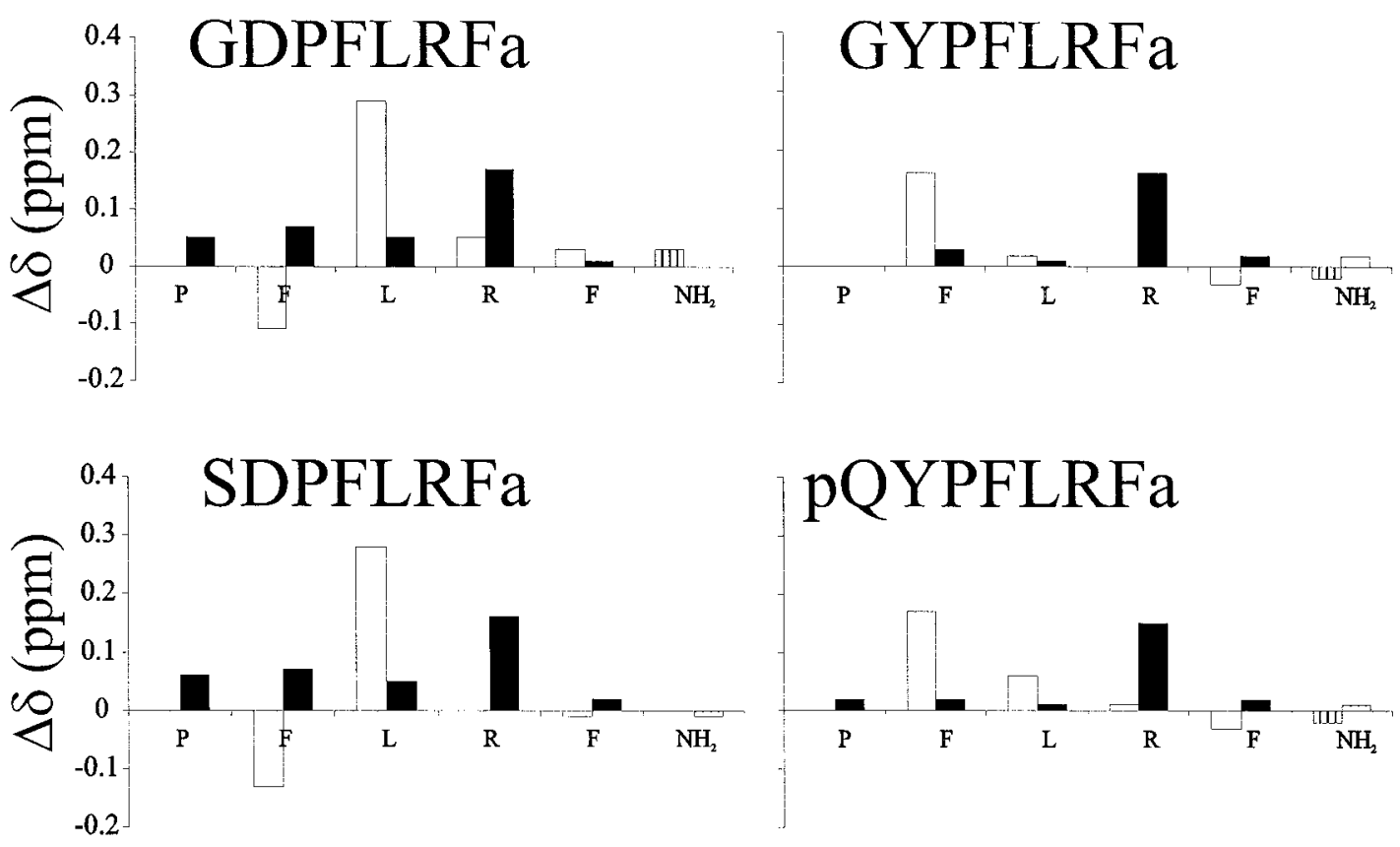

Figure 1. Deviations from random coil values (Wishart and Sykes, 1994) of $\mathrm{H}^{\mathrm{N}}$ (open bars) and $\mathrm{H}^{\alpha}$ (solid bars) chemical shifts. The C-terminal amide values were subtracted from the average of all the values recorded in this study. Vertical axes are in parts per million, and the horizontal axes represent the conserved PNFLRF-NH $\mathrm{N}_{2}$ region of each peptide. The peptide pQYPFLRFa had a significant amount of overlap and conformational heterogeneity, preventing us from making complete assignments of all the side-chains, but the backbone assignments shown in Figure 1 are complete. Data were collected at approximately $\mathrm{pH} 5.5$ and $4^{\circ} \mathrm{C}$.

conformational ensemble of each peptide. The major feature of Figure 1 is that the peptides can be classified into DPFLRF-NH (DP) and YPFLRF-NH $\mathrm{H}_{2}$ (YP) subgroups. It must be reemphasized that the shifts presented in Figure 1 are common to all peptides. Therefore, chemical shift data show that long-range conformational changes occur in these peptides as a result of the amino acid $\mathrm{N}$ terminal to the proline. A second feature of Figure 1 is that the deviations from random coil chemical shift values, in general, are larger for the DP than for the YP subgroup, suggesting that the DP peptides have higher populations of "nonrandom" conformations.

\section{Internuclear distances}

Chemical shifts are extremely sensitive to molecular conformation and thus provide a good probe for comparing similar molecules. However, details about particular conformations such as turns can best be obtained by direct measurement of internuclear distances. Two-dimensional ROESY experiments yield cross peaks between protons closer than $5 \AA$ in space; the closer the protons, the stronger the peak.

Figure 2 shows the $\alpha$-to-amide and amide-to-amide regions of ROESY spectra from GDPFLRF-NH $\mathrm{H}_{2}$ and GYPFLRF-NH $\mathrm{H}_{2}$, which are representative of other DP and YP peptides. One of the most notable features in Figure 2 is the large difference in the amide region (bottom panels) between the two peptides. The ROESY spectrum of GDPFLRF-NH $\mathrm{H}_{2}$ has strong cross peaks between the amide protons of $\mathrm{F} 4$ and $\mathrm{L} 5$ and weaker peaks between L5 and R6. In contrast, GYPFLRF-NH $\mathrm{H}_{2}$ has no measurable amide-to-amide cross peaks except between F7 and the $\mathrm{NH}_{2}$ group (not included in Fig. 2), a feature present in all of the dozens of amidated peptides that we have studied (our unpublished observations). The pattern of ROESY amide-to-amide cross peaks in GDPFLRF- $\mathrm{NH}_{2}$ is consistent with a reverse turn
(Dyson et al., 1988a); the lack of similar ROESY cross peaks in GYPFLRF- $\mathrm{NH}_{2}$ indicates that it is extended or randomly oriented.

The $\alpha$-to-amide region (Fig. 2, top panels) shows two main features. First, GYPFLRF- $\mathrm{NH}_{2}$ has significant heterogeneity associated with the two forms (cis and trans) of the Y-P peptide bond. GDPFLRF- $\mathrm{NH}_{2}$, on the other hand, is predominantly trans, with $<10 \%$ of the population in the cis form. All peptides examined in this study had trans X-Pro peptide bonds as the major species, as evidenced by ROESY cross peaks between Pro- $\mathrm{H}^{\delta}$ and $\mathrm{X}-\mathrm{H}^{\alpha}$ or $\mathrm{X}-\mathrm{H}^{\beta}$ (Dyson et al., 1988a,b). We estimate that $\sim 90 \%$ of the DP and $70 \%$ of the YP subgroups have trans $\mathrm{X}$-Pro peptide bonds. Second, the chemical shift dispersion, a good indicator of structure, is greater in GDPFLRF-NH $\mathrm{H}_{2}$ than in GYPFLRF-NH $\mathrm{H}_{2}$.

Interactions between amide protons of adjacent amino acids are particularly sensitive to secondary structure: amide-to-amide distances are large in extended structures but short in turns or helical structures. In contrast, the distance between an $\alpha$ proton of one amino acid and the amide proton of the next amino acid is characteristically short for extended structures but long in turns or helical structures (Wüthrich, 1986; Dyson et al., 1988a,b). Thus, the ratio of the intensity of ROESY amide-to-amide and $\alpha$-to-amide cross peaks $\left(I_{\mathrm{NN}} / I_{\alpha \mathrm{N}}\right)$ can provide a measure of the percentage of compact structure (Bradley et al., 1990). Table 1 lists $I_{\mathrm{NN}} / I_{\alpha \mathrm{N}}$ values for interactions between F4 and L5 for all of the peptides in this study. The $I_{\mathrm{NN}} / I_{\alpha \mathrm{N}}$ values range from 0.0 for all of the YP peptides to $>1.5$ for the DP peptides. These numbers will be more thoroughly examined in Discussion.

All of the data presented to this point have been collected at $4^{\circ} \mathrm{C}$ to match experimental binding conditions (see Discussion). For two of the peptides (GDPFLRF-N $\mathrm{H}_{2}$ and SDPFLRF-NH $\mathrm{H}_{2}$ ), 


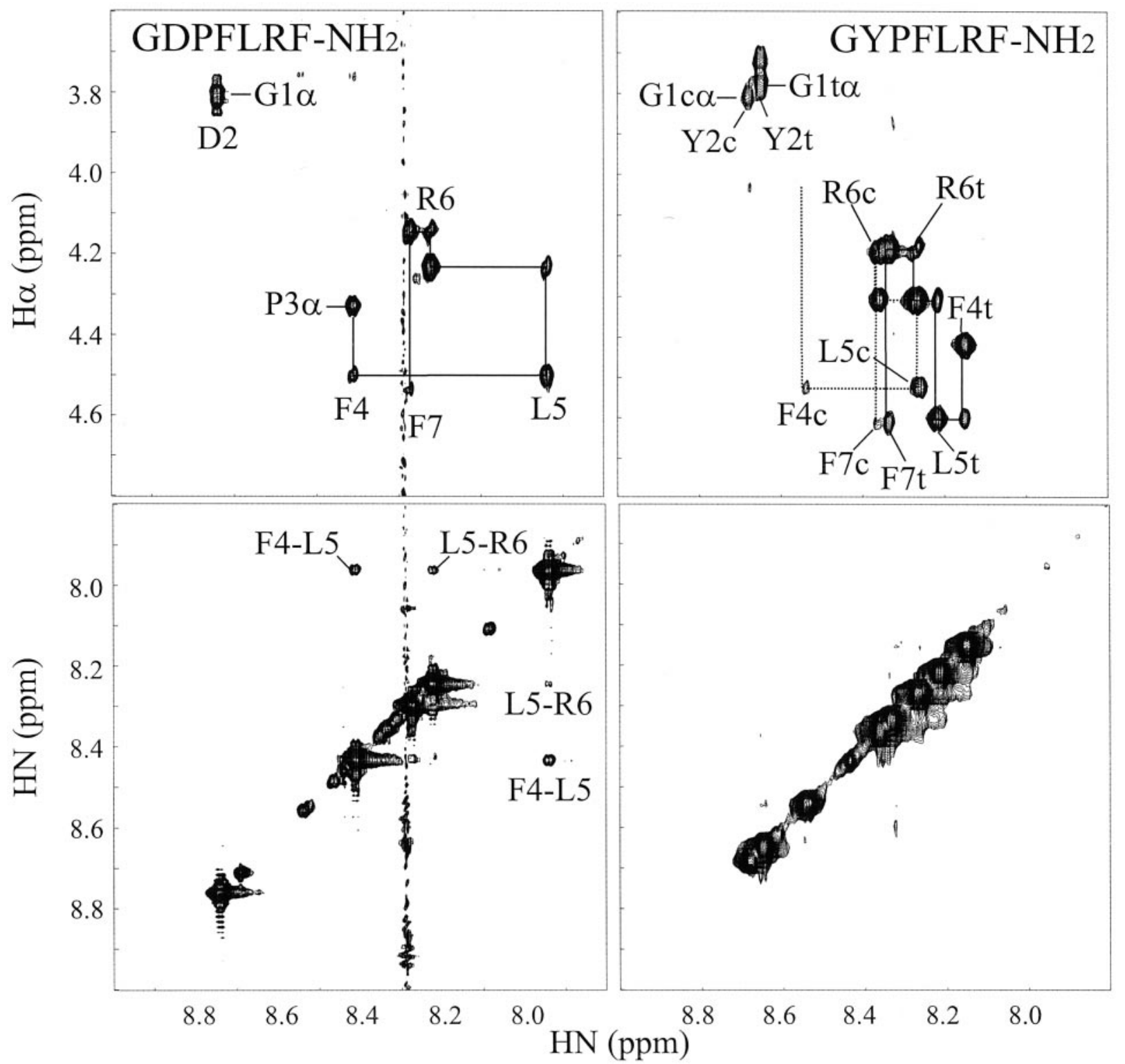

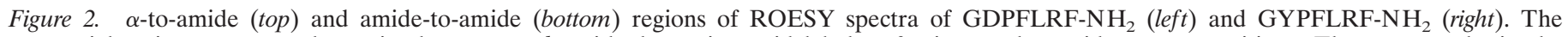
sequential assignments are shown in the top panels, with the amino acid labels referring to the amide proton positions. The cross peaks in the amide-to-amide region representing the more compact structure in GDPFLRF- $\mathrm{NH}_{2}$ are labeled. The stripe at $8.3 \mathrm{ppm}$ in the GDPFLRF-NH $\mathrm{H}_{2}$ spectrum was an instrumental artifact. The temperature for both spectra was $4^{\circ} \mathrm{C}$, the $\mathrm{pH}$ was $\sim 5.5$, and mixing times were $250 \mathrm{msec}$.

we collected ROESY data at higher temperatures. To our surprise, the $I_{\mathrm{NN}} / I_{\alpha \mathrm{N}}$ values became larger as the temperature increased, suggesting that the turn population increases at room temperature.

\section{pH dependence}

The $\mathrm{pH}$ dependence of the chemical shifts of titratable groups in peptides can provide important data about hydrogen bonding (Bundi and Wüthrich, 1979). Within the $\mathrm{pH}$ range investigated in this study (1.9-5.5), the only titratable group in the peptides of Table 1 is aspartic acid (D). Generally, the peptide $\mathrm{C}$ terminus is titratable, but each peptide in this study has a $\mathrm{C}$-terminal amide because all of the FLPs are amidated in vivo. Amide, $\alpha$, and side-chain protons within aspartic or glutamic acids undergo intrinsic shifts that, in general, contain little conformational in- formation. Protons outside of titratable amino acids often show little or no dependence on $\mathrm{pH}$. However, protons that interact closely through hydrogen bonding with carboxylic acid side-chains will exhibit chemical shift changes as a function of $\mathrm{pH}$ and thus provide direct evidence of long-range interactions.

Figure 3 shows the $\mathrm{pH}$ dependence of the amide protons of GDPFLRF-NH $H_{2}$, pQDPFLRF-NH $\mathrm{N}_{2}$, and DPFLRF-NH $\mathrm{H}_{2}$. The other XDPFLRF-NH $\mathrm{H}_{2}(\mathrm{X}=\mathrm{S}, \mathrm{N})$ peptides were similar to GDPFLRF-NH $\mathrm{H}_{2}$ and are not shown. Each peptide shows the characteristic upfield shift of the aspartic acid (D) $\mathrm{H}^{\mathrm{N}}$ (Bundi and Wüthrich, 1979) and very large downfield shifts of the amide protons of the phenylalanine after the proline. These data clearly demonstrate strong hydrogen bonding interactions between the carboxylate side-chain of aspartic acid and the amide proton of phenylalanine-4 (F4) in GDPFLRF-NH $H_{2}$. The smaller magnitude 
Figure 3. Amide regions of onedimensional $\mathrm{pH}$ titrations for GDPFLRF$\mathrm{NH}_{2}$ (top), pQDPFLRF-NH ${ }_{2}$ (middle), and DPFLRF-NH $\mathrm{H}_{2}$ (bottom). The total magnitudes (highest $\mathrm{pH}$ minus lowest $\mathrm{pH}$ ) of the changes in the phenylalanine chemical shift for each peptide studied are shown in Table 1. Series of onedimensional ${ }^{1} \mathrm{H}$ spectra are drawn from lowest to highest $\mathrm{pH}$ (bottom to top), with some of the values of $\mathrm{pH}$ indicated. Minor peaks in the spectra correspond to cis $\mathrm{D}-\mathrm{P}$ peptide bonds. All data were collected at $4^{\circ} \mathrm{C}$.

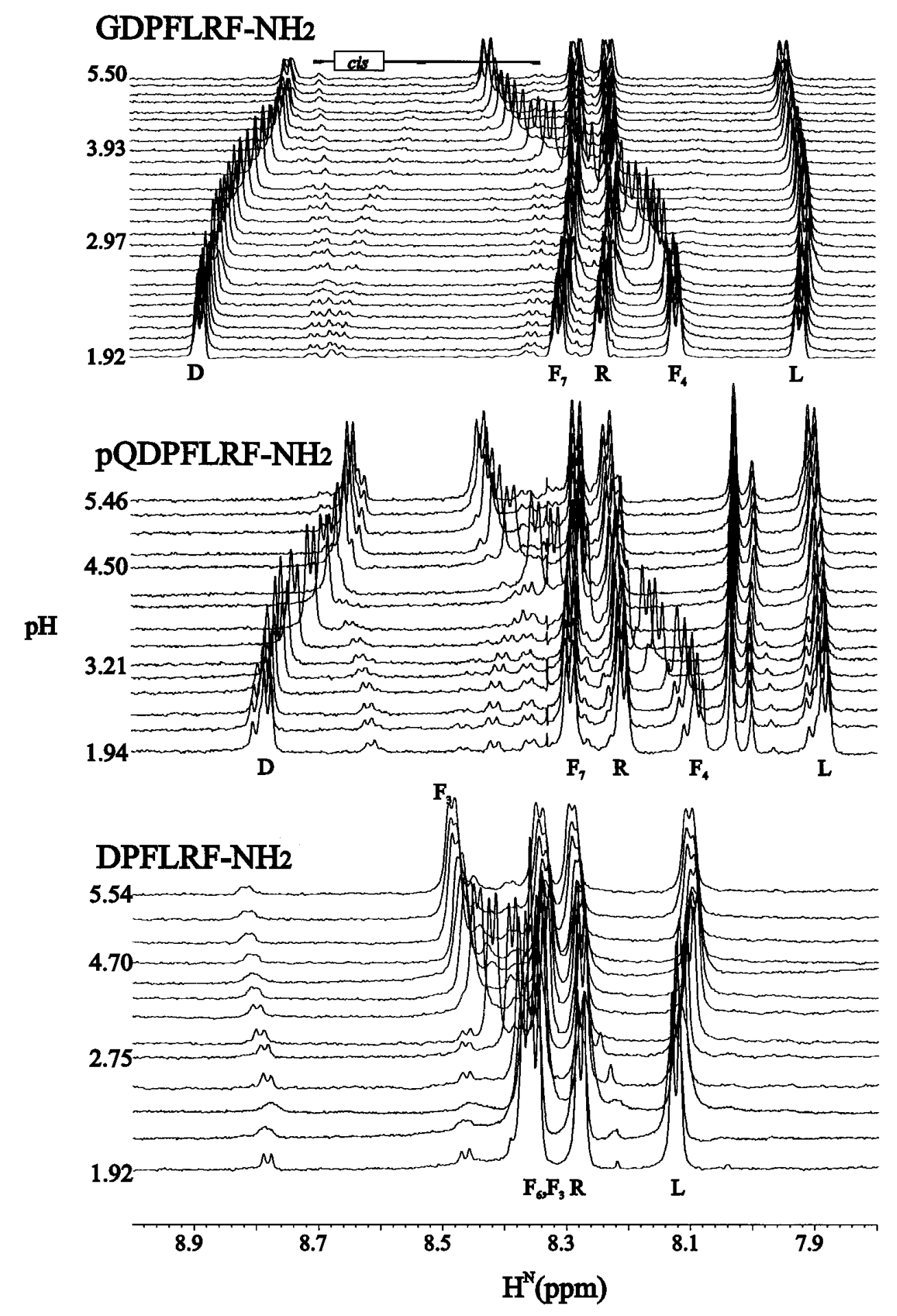




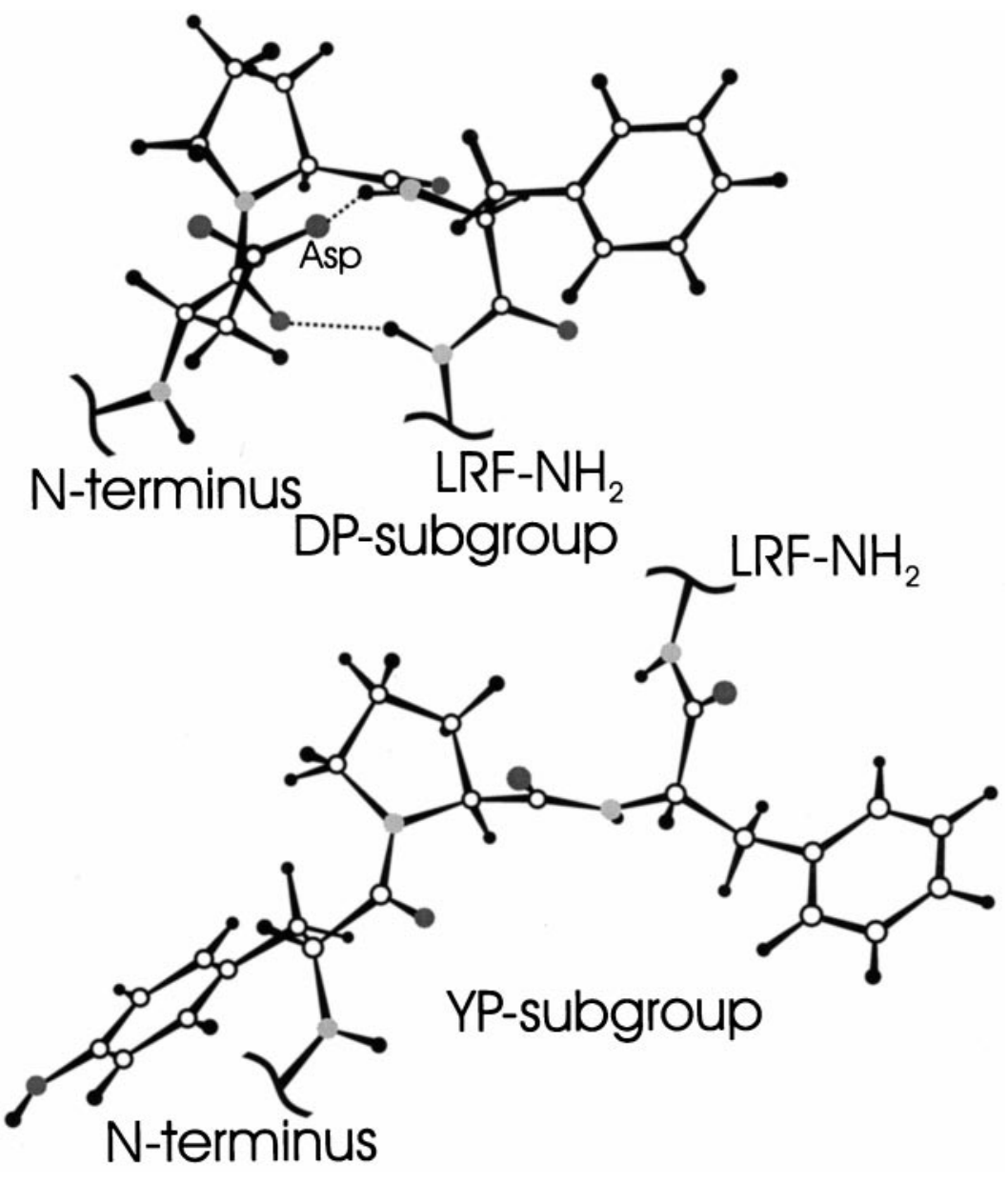

Figure 4. Molecular models of DP (top) and YP (bottom) subgroups. Both models include the amino acids XPF (X = $\mathrm{D}$ or $\mathrm{Y}$ ) and the amide group of $\mathrm{L}$. The top is a type I reverse turn with a geometry that is consistent with the NMR data, including the close proximity of the D sidechain to the $\mathrm{F}$ amide proton and the $\mathrm{F}$ and $\mathrm{L}$ amide protons. The YP subgroup was drawn in one of many possible extended structures, representing a complete lack of close contacts seen in the DP peptides. The YP model and all amino acids not represented here from both groups are completely averaged. Models were made using Insight II (Biosym). aspartic acid and proline are very commonly found in the first and second positions, respectively, of type I turns (Wilmot and Thornton, 1988). Second, crystal structures of proteins with DP in the first two positions of a type I turn often reveal the aspartic acid side-chain hydrogen bonded to the amide proton of amino acid after the proline (Wilmot and Thornton, 1988). This hydrogen bonding is identical to what we observe through the $\mathrm{pH}$ titration data, with large downfield shifts of the amide protons of the phenylalanine after the proline.

Models that are consistent with the NMR data for both the DP and YP peptides are shown in Figure 4. The most populated conformation in the DP peptides is a turn, and the YP peptides do not have any well defined structure. In addition, we see no well defined structure in the entire "LRF- $\mathrm{NH}_{2}$ " C-terminal region in any of the peptides. The conserved $\mathrm{C}$ terminus is directly involved in receptor binding and must be able to fit into an active site, and our data suggest that this fit requires a flexible group.

\section{DISCUSSION}

\section{Receptor binding studies}

The peptides for this study were chosen because of previously published detailed physiological and ligand displacement studies of the same peptides on membrane preparations from the brains of the snail Helix aspersa (Payza, 1987; Payza et al., 1989). The receptor binding results most relevant to this study are shown in Table 2.

Table 2 shows that the peptides with the sequence XDPFLRFa $(\mathrm{X}=\mathrm{S}, \mathrm{N}, \mathrm{pQ})$ need between 3 and 20 times the concentration
Table 2. Summary of receptor binding studies in Helix brain $^{a}$

\begin{tabular}{lc} 
Peptide $^{b}$ & $\mathrm{IC}_{50}(\mu \mathrm{M})^{c}$ \\
\hline FMRFa & 0.53 \\
FLRFa & 1.3 \\
PFLRFa & 0.86 \\
DPFLRFa & 3.4 \\
NDPFLRFa & 9 \\
SDPFLRFa & 15 \\
pQDPFLRFa & 10 \\
pQYPFLRFa & 0.22 \\
daYPFLRFa & 0.20
\end{tabular}

${ }^{a}$ This table is composed from data in Table 2 of Payza et al. (1989).

${ }^{b}$ Abbreviations include "a" = $\mathrm{NH}_{2}$, "pQ" = pyroglutamic acid, "da" = des-amino, "nL" = norleucine.

${ }^{c}$ Concentration needed to displace $50 \%{ }^{125} \mathrm{I}$-da YFnLRFa from a Helix brain membrane preparation.

to displace a reporter molecule than FLRFa, PFLRFa, or DPFLRFa. These effects are not simply a result of a peptide that is too long, as illustrated by the high receptor affinity of pQYPFLRFa (almost 10 times greater than FLRFa). Nor can these results be easily understood in terms of unfavorable interactions with the receptor because, for example, the $\mathrm{pQ}$ at the $\mathrm{N}$ terminus of DPFLRFa lowers the receptor affinity by a factor of three, whereas $\mathrm{pQ}$ at the $\mathrm{N}$ terminus of daYPFLRFa has no effect on binding. 
Figure 5. Plots of $I_{\mathrm{NN}} / I_{\alpha \mathrm{N}}$ (small black dots and solid line) and $\mathrm{pH}$ titration (large gray dots and dotted line) data versus $\mathrm{IC}_{50}$ measurements. The vertical axis is parts per million for the $\mathrm{pH}$ titration and unitless for $I_{\mathrm{NN}} / I_{\alpha \mathrm{N}}$. The $\mathrm{IC}_{50}$ data represent the concentration of peptide needed to displace $50 \%$ of ${ }^{125}$ I-daYFnLRF-NH $\mathrm{H}_{2}$ from a Helix brain membrane preparation (Payza, 1987; Payza et al., 1989). The $I_{\mathrm{NN}} / I_{\alpha \mathrm{N}}$ and $\mathrm{pH}$ titration data are from Table 1 and are described in the text. Data were fit to linear equations, $\mathrm{IC}_{50}=a(\mathrm{NMR})+b$ $\left(I_{\mathrm{NN}} / I_{\alpha \mathrm{N}}\right.$ data: $a=33.33, b=$ $-0.27, r^{2}=0.93 ; \mathrm{pH}$ data: $a=$ 41.67, $\left.b=-1.79, r^{2}=0.82\right)$. A data point for the $\mathrm{pH}$ dependence of pQYPFLRF- $\mathrm{NH}_{2}$ at $0 \mathrm{ppm}$ was added, because there is no titratable group and thus no $\mathrm{pH}$ dependence.

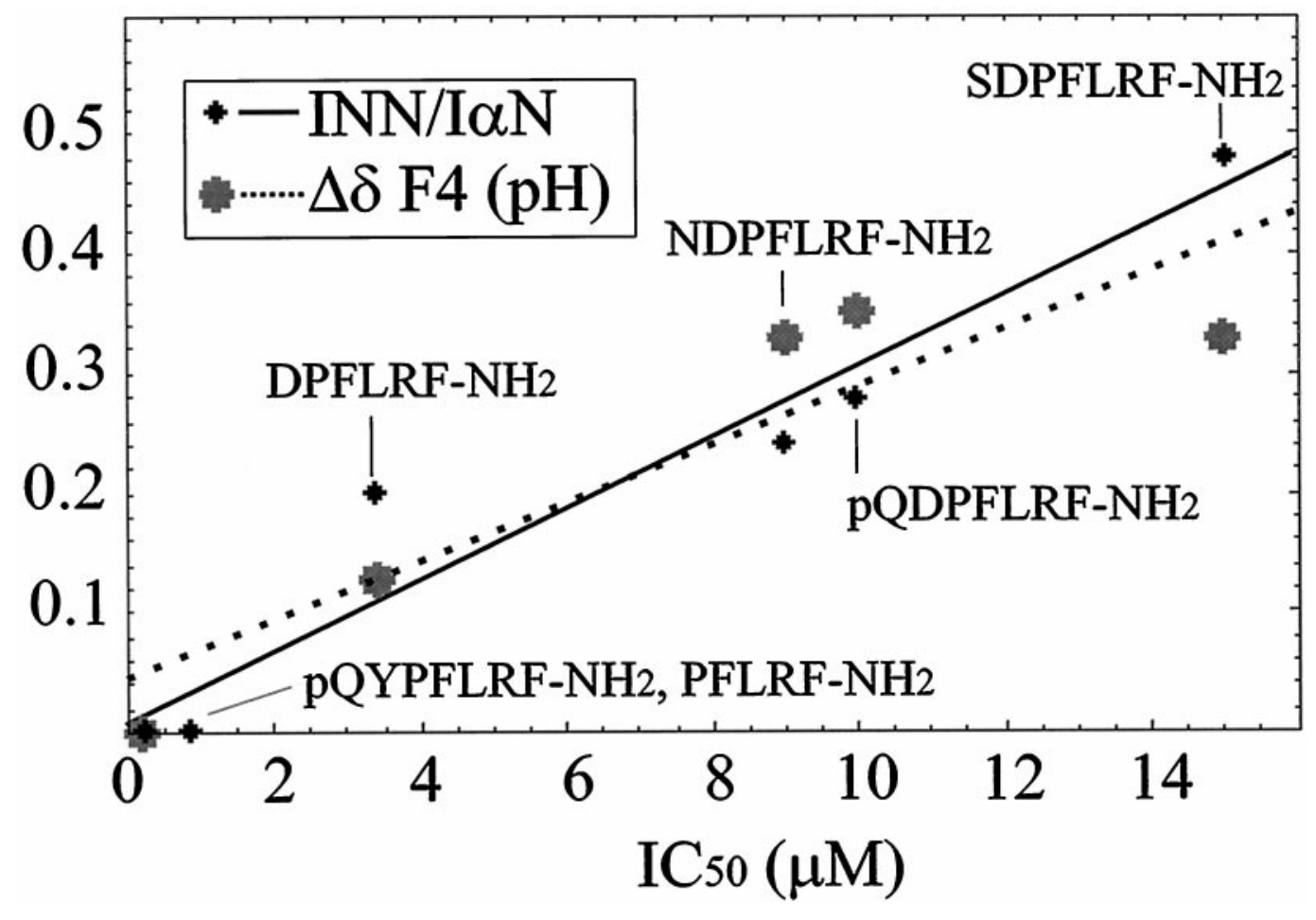

\section{Comparison of NMR and receptor binding experimental conditions}

The receptor binding experiments were performed with assay buffer of $80 \mathrm{~mm}$ piperazine- $n, n^{\prime}$-bis(2-hydroxypropanesulfonic acid), pH 7.9, 1\% BSA (Payza, 1987; Payza et al., 1989). To minimize the degradation of peptides, the receptor binding assays were performed on ice at $0^{\circ} \mathrm{C}$.

NMR measurements have several experimental constraints. First, for solution studies in aqueous samples, the temperature must be above freezing. We used $4^{\circ} \mathrm{C}$ for most of the NMR results presented in this report. Second, amide protons exchange too rapidly for observation around $\mathrm{pH}$. The $\mathrm{pH}$ titrations shown above clearly demonstrate that at around $\mathrm{pH} 5.5$, the aspartic acid side-chains are fully deprotonated; no further change in these or any other side-chains will take place as the $\mathrm{pH}$ is increased. The $\mathrm{N}$-terminal amino group is the only part of the peptides that would still be affected by differences in $\mathrm{pH}$ between the binding and NMR studies. Third, NMR measurements are notoriously insensitive and require close to $1 \mathrm{~mm}$ concentrations of sample, leading to the possibility of aggregation. We tested for aggregation in each sample by making 10 -fold dilutions and recording one-dimensional ${ }^{1} \mathrm{H}$ spectra. In the dilution studies, no peak moved more than $0.02 \mathrm{ppm}$, demonstrating that aggregation is negligible at the concentrations used for NMR analysis. Finally, NMR is sensitive to salt concentrations, so all of the data presented above are in the minimal salt needed to adjust the $\mathrm{pH}$. To rule out effects of salt, we added $150 \mathrm{~mm} \mathrm{KCl}$ to each sample and measured the one-dimensional ${ }^{1} \mathrm{H}$ spectra. As with the dilution studies, we saw no change in chemical shift $>0.02 \mathrm{ppm}$ between high- and low-salt conditions, demonstrating that $\mathrm{KCl}$ has little or no influence on these samples.

Thus, we are confident that the NMR experimental conditions are at least relevant, if not closely matched, to the receptor binding assays. The only factor that we suspect may be different between the binding and NMR data is the degree of protonation of the N-terminal amino groups between $\mathrm{pH} 5.5$ and 7.9.

\section{Comparison of NMR and receptor binding results}

Figure 5 is a plot of the measured NMR parameters that are sensitive to turn population $\left(I_{\mathrm{NN}} / I_{\alpha \mathrm{N}}\right.$ and $\mathrm{pH}$ shifts from Table 1$)$ versus the $\mathrm{IC}_{50}$ values measured for the same peptides (Payza, 1987; Payza et al., 1989). Both NMR parameters increase with increasing values of $\mathrm{IC}_{50}$. The simplest interpretation of the NMR data is a rapid two-state equilibrium between a reverse turn and fully extended structure. For the DP peptides, the equilibrium is shifted in varying amounts toward the turn. For the YP peptides and PFLRF-NH $\mathrm{H}_{2}$, the equilibrium is nearly $100 \%$ in favor of the extended structure.

A simple two-state model will lead to a linear relationship between the percentage of turn and the magnitude of both $I_{\mathrm{NN}} /$ $I_{\alpha \mathrm{N}}$ and the $\mathrm{pH}$ shifts. Thus, we used a linear relationship to fit the NMR parameters to the $\mathrm{IC}_{50}$ data. The correlation coefficients $\left(r^{2}\right)$ for the fits were quite good at 0.93 and 0.82 for the $I_{\mathrm{NN}} / I_{\alpha \mathrm{N}}$ and $\mathrm{pH}$ data, respectively. Deviations from linearity could result from either more than two predominant conformations in the unbound state or from additional (or different) factors involved in the binding data, such as direct interactions (favorable or unfavorable) between the ligands and receptor. The effects of multiple conformations are currently under investigation in modeling studies. We present a number of $\mathrm{IC}_{50}$ predictions below to further test our model.

\section{Biological roles of conformational ensembles}

The strong linear structure-function relationships in Figure 5 suggest that the observed $\mathrm{IC}_{50}$ data can best be explained by the conformation of the unbound peptides. Namely, peptides with high populations of turn displace radio-labeled ligands at higher concentrations, and the turns are preventing the peptides from interacting with the receptors in the binding assay. These rela- 
tionships suggest a simple modification to elementary ligandreceptor equations. In the simplest case of binding, a ligand $(L)$ binds to a receptor $(R)$ to form a ligand-receptor complex $(L R)$ with an equilibrium dissociation constant $K_{\text {eq }}$ :

$$
L+R \rightleftarrows L R \text {. }
$$

The fraction of bound receptors $\left(P_{\mathrm{B}}\right)$ for this simple equilibrium is:

$$
P_{\mathrm{B}}=\frac{[L]}{[L]+K_{\mathrm{eq}}} .
$$

The effect of our model is to reduce the active form of the ligand to $L^{\mathrm{A}}$, which in the current study represents peptides in extended or random conformations:

$$
L^{\mathrm{I}} \rightleftarrows L^{\mathrm{A}} \text {. }
$$

The inactive form of the ligand, $L^{\mathrm{I}}$ (here representing molecules in a turn conformation), is not able to bind directly to the receptor, thus reducing the fraction of bound receptors:

$$
P_{\mathrm{B}}=\frac{\left\lfloor L^{\mathrm{A}}\right\rfloor}{\left[L^{\mathrm{A}}\right]+K_{\mathrm{eq}}} .
$$

It must be stressed that active or inactive forms of a ligand are defined with respect to a particular receptor.

The model and data described above apply to a single peptide ligand and a single receptor that binds the active ligand $\left(L^{\mathrm{A}}\right)$ conformation. However, receptor heterogeneity can play a large role in our model. As described above, the role of conformational ensembles of a single ligand interacting with a single receptor will lead to changes in the bound population of that receptor. If there is a second receptor that preferentially binds to the inactive form (defined with respect to the first receptor) of the same ligand, then more complicated signaling can occur. Depending on the degree of coupling between the two receptors, the resultant signals from the two different conformations of the peptide could be divergent or convergent, leading to increased "physiological flexibility" (Brezina et al., 1996).

Payza and coworkers found that the Helix XDPFLRF-NH $\mathrm{H}_{2}$ peptides have a complicated physiology. At concentrations $<0.03$ $\mu \mathrm{M}$ they are $\sim 30-50$ times more cardiostimulatory than FMRF$\mathrm{NH}_{2}$, but at concentrations $>0.03 \mu \mathrm{M}$ they are cardioinhibitory (Payza, 1987). From these observations, Payza hypothesized that the XDPFLRF-NH $\mathrm{H}_{2}$ peptides must interact with different or additional receptors. We showed above that the XDPFLRF-NH peptides have up to $\sim 80 \%$ reverse turn in solution. Therefore, if we assume that the XDPFLRF- $\mathrm{NH}_{2}$ peptides bind with the same affinity to both the stimulatory and inhibitory receptors, then our model would predict that stimulatory receptor preferentially binds the turn conformation (dominant conformation) and the inhibitory receptor preferentially binds the extended conformation (minor conformation). Clearly, more data are needed to prove this relationship.

There are currently two cloned FLP receptors: a peptide-gated sodium channel (Green et al., 1994; Linguelglia et al., 1995) and a G-protein-coupled receptor (Tensen et al., 1998). In addition to the two sequences, several other FLP receptors have been biochemically characterized (Payza, 1987; Payza et al., 1989; Chin et al., 1994; Wang et al., 1995a,b). All available evidence, therefore, points to the presence of multiple FLP receptors (Tensen et al., 1998). We hypothesize that the effect of conformational ensem- bles in differential binding to multiple receptors will be widespread.

Most of the focus in ligand-receptor interactions has naturally involved the ligand-receptor complex, and these direct contacts with receptors are obviously important. However, our data clearly show the importance of the unbound conformational state in ligand-receptor interactions. From our model we can make a number of predictions for future binding assays under the same conditions used by Payza and coworkers (1987, 1989). (1) On the basis of our NMR measurements (Table 1), GDPFLRF-NH $\mathrm{H}_{2}$ and GYPFLRF-NH$H_{2}$ will have $\mathrm{IC}_{50}$ values of $13 \mu \mathrm{M}$ and $<1 \mu \mathrm{M}$, respectively. (2) YDPFLRF-NH$H_{2}$ will have $\mathrm{IC}_{50}$ values near the other DP peptides (10-15 $\mu \mathrm{M})$. (3) SDZPFLRF-NH $\mathrm{H}_{2}$ (Z any amino acid except $\mathrm{D}, \mathrm{N}$, or $\mathrm{P}$ ) will have $\mathrm{IC}_{50}$ values near the $\mathrm{YP}$ or tetra-peptides $(<1 \mu \mathrm{M})$. (4) SNPFLRF-NH $\mathrm{H}_{2}$ will have $\mathrm{IC}_{50}$ values near SDPFLRF-NH $\mathrm{H}_{2}(15 \mu \mathrm{M})$, because asparagine $(\mathrm{N})$ has hydrogen bonding properties and type I turn propensities (Wilmot and Thornton, 1988) similar to those of aspartic acid (D).

We have demonstrated that populations of reverse turns in a series of neuropeptides are inversely correlated with their receptor-binding affinities. This finding suggests that one of the roles for diverse N-terminal amino acid sequences in FLPs is to provide different unbound conformational ensembles and thus lead to different receptor binding affinities.

\section{REFERENCES}

Bargmann CI (1998) Neurobiology of the Caenorhabditis elegans genome. Science 282:2028-2033.

Bothner-By AA, Stephens RL, Lee J, Warren CD, Jeanloz RW (1984) Structure determination of a tetrasaccharide: transient nuclear Overhauser effects in the rotating frame. J Am Chem Soc 106:811-813.

Bradley EK, Thomason JF, Cohen FE, Kosen PA, Kuntz ID (1990) Studies of synthetic helical peptides using circular dichroism and nuclear magnetic resonance. J Mol Biol 215:607-622.

Braunschweiler L, Ernst RR (1983) Coherence transfer by isotropic mixing: application to protein correlation spectroscopy. J Magn Reson 53:521-528.

Brezina V, Orekhova IV, Weiss KR (1996) Functional uncoupling of linked neurotransmitter effects by combinatorial convergence. Science 273:806-810.

Bundi A, Wüthrich K (1979) Use of amide ${ }^{1} \mathrm{H}-\mathrm{NMR}$ titration shifts for studies of polypeptide conformation. Biopolymers 18:299-311.

Callihan D, West J, Kumar S, Schweitzer BI, Logan TM (1996) Simple, distortion-free homonuclear spectra of peptides and nucleic acids in water using excitation sculpting. J Magn Reson B 112:82-85.

Chin GJ, Payza K, Price DA, Greenberg MJ, Doble KE (1994) Characterization and solubilization of the FMRFamide receptor of squid. Biol Bull 187:185-189.

Cowden C, Stretton AOW (1993) AF2, an Ascaris neuropeptide: isolation, sequence, and bioactivity. Peptides 14:423-430.

Cowden C, Stretton AOW (1995) Eight novel FMRFamide-like neuropeptides isolated from the nematode Ascaris suum. Peptides 16:491-500.

Cowden C, Stretton AOW, Davis RE (1989) AF1, a sequenced bioactive neuropeptide isolated from the nematode Ascaris suum. Neuron 2:1465-1473.

Creighton TE (1993) Proteins: structures and molecular properties. New York: W. H. Freeman.

Davis RE, Stretton AOW (1996) The motornervous system of Ascaris: electrophysiology and anatomy of the neurons and their control by neuromodulators. Parasitology 113:S97-S117.

Delaglio F, Grzesiek S, Vuister G, Zhu G, Pfeifer J, Bax A (1995) NMRPipe: a multidimensional spectral processing system based on UNIX Pipes. J Biomol NMR 6:277-293.

Dickinson PS, Mecsas C, Marder E (1990) Neuropeptide fusion of two motor-pattern generator circuits. Nature 344:155-158.

Dyson HJ, Rance M, Houghten RA, Lerner RA, Wright PE (1988a) Folding of immunogenic peptide fragments of proteins in water solution. I. Sequence requirements for the formation of a reverse turn. J Mol Biol 201:161-200. 
Dyson HJ, Rance M, Houghten RA, Wright PE, Lerner RA (1988b) Folding of immunogenic peptide fragments of proteins in water solution: II. The nascent helix. J Mol Biol 201:201-217.

Džakula Z̆, Westler WM, Edison AS, Markley JL (1992) The CUPID method for calculating the continuous probability distribution of rotamers from NMR data. J Am Chem Soc 114:6195-6199.

Edison AS, Messinger LA, Stretton AOW (1997) afp-1: A gene encoding multiple transcripts of a new class of FMRFamide-like neuropeptides in the nematode Ascaris suum. Peptides 18:929-935.

Green KA, Falconer SWP, Cottrell GA (1994) The neuropeptide FMRFamide directly gates two ion channels in an identified Helix neurone. Pflügers Arch 428:232-240.

Greenberg MJ, Price DA (1992) Relationships among the FMRFamidelike peptides. In: Progress in brain research (Joosse J, Buijs RM, Tilders FJH, eds), pp 25-37. Amsterdam: Elsevier.

Jardetzky O (1980) On the nature of molecular conformations inferred from high-resolution NMR. Biochim Biophys Acta 621:227-232.

Johnson BA, Blevins RA (1994) NMRView: a computer program for the visualization and analysis of NMR data. J Biomol NMR 4:603-614.

Kellett E, Saunders SE, Li KW, Staddon JW, Benjamin PR, Burke JF (1994) Genomic organization of the FMRFamide gene in Lymnaea: multiple exons encoding novel neuropeptides. J Neurosci 14:6564-6570.

Linacre A, Kellett E, Saunders S, Bright K, Benjamin PR, Burke JF (1990) Cardioactive neuropeptide FMRFamide and novel related peptides are encoded in multiple copies by a single gene in the snail Lymnaea stagnalis. J Neurosci 10:412-419.

Linguelglia E, Champigny G, Lazdunski M, Barbry P (1995) Cloning of the amiloride-sensitive FMRFamide peptide-gated sodium channel. Nature 378:730-733.

Lutz EM, MacDonald M, Hettle S, Price DA, Cottrell GA, Sommerville J (1992) Structure of cDNA clones and genomic DNA encoding FMRFamide-related peptides (FaRPs) in Helix. Mol Cell Neurosci 3:373-382.

Mayo KH, Parra-Diaz D, McCarthy JB, Chelberg M (1991) Cell adhesion promoting peptide GVKGDKGNPGWPGAP from the collagen type IV triple helix: cis/trans proline-induced multiple ${ }^{1} \mathrm{H}$ NMR conformations and evidence for a $\mathrm{KG} / \mathrm{PG}$ multiple turn repeat motif in the all-trans proline state. Biochemistry 30:8251-8267.

Miick SM, Martinez GV, Fiori WR, Todd AP, Millhauser GL (1992) Short alanine-based peptides may form $3_{10}$-helices and not $\alpha$-helices in aqueous solution. Nature 359:653-655.

Millhauser GL, Stenland CJ, Bolin KA, van de Ven FJM (1996) Local helix content in an alanine-rich peptide as determined by the complete set of ${ }^{3} \mathrm{~J}_{\mathrm{HN} \alpha}$ coupling constants. J Biomol NMR 7:331-334.

Nelson LS, Rosoff ML, Li C (1998) Disruption of a neuropeptide gene, flp-1, causes multiple behavioral defects in Caenorhabditis elegans. Science 281:1686-1690.

Oldfield E (1995) Chemical shifts and three dimensional protein structures. J Biomol NMR 5:217-225.

Payza K (1987) FMRFamide receptors in Helix aspersa. Peptides 8:1065-1074.

Payza K, Greenberg MJ, Price DA (1989) Further characterization of Helix FMRFamide receptors: kinetics, tissue distribution, and interactions with the endogenous heptapeptides. Peptides 10:657-661.

Price DA, Greenberg MJ (1977) Structure of a molluscan cardioexcitatory neuropeptide. Science 197:670-671.

Price DA, Lesser W, Lee TD, Doble KE, Greenberg MJ (1990) Seven FMRFamide-related and two SCP-related cardioactive peptides from Helix. J Exp Biol 154:421-437.
Rosoff ML, Bürglin TR, Li C (1992) Alternatively spliced transcripts of the $f l p-1$ gene encode distinct FMRFamide-like peptides in Caenorhabditis elegans. J Neurosci 12:2356-2361.

Sakurai T, Amemiya A, Ishii M, Matsuzaki I, Chemelli RM, Tanaka H, Williams SC, Richardson JA, Kozlowski GP, Wilson S, Arch FRS, Buckingham RE, Haynes AC, Carr SA, Annan RS, McNulty DE, Liu W-S, Terrett JA, Elshourbagy NA, Bergsma DJ, Yanagisawa M (1998) Orexins and orexin receptors: a family of hypothalamic neuropeptides and $\mathrm{G}$ protein-coupled receptors that regulate feeding behavior. Cell 92:573-585.

Saunders SE, Bright K, Kellett E, Benjamin PR, Burke JF (1991) Neuropeptides GDPFLRFamide and SDPFLRFamide are encoded by an exon $3^{\prime}$ to FMRFamide in the snail Lymnaea stagnalis. J Neurosci $11: 740-745$.

Simon TW, Opdyke CA, Calabrese RL (1992) Modulatory effects of FMRF- $\mathrm{NH}_{2}$ on outward currents and oscillatory activity in heart interneurons of the medicinal leech. J Neurosci 12:525-537.

Sossin WS, Fisher JM, Scheller RH (1989) Cellular and molecular biology of neuropeptide processing and packaging. Neuron 2:1407-1417.

States DJ, Haberkorn RA, Ruben DJ (1982) A two dimensional nuclear Overhauser experiment with pure absorption phase in four quadrants. J Magn Reson 48:286-292.

Taussig R, Scheller RH (1986) The Aplysia FMRFamide gene encodes sequences related to mammalian brain peptides. DNA 5:453-461.

Tensen CP, Cox KJA, Smit AB, van der Schors RC, Meyerhof W, Richter D, Planta RJ, Hermann PM, van Minnen J, Geraerts WPM, Knol JC, Burke JF, Vreugdenhil E, van Heerikhuizen H (1998) The Lymnaea cardioexcitatory peptide (LyCEP) receptor: a G-protein-coupled receptor for a novel member of the RFamide neuropeptide family. J Neurosci 18:9812-9821.

Wang Z, Orchard I, Lange AB, Chen X, Starratt AN (1995a) A single receptor transduces both inhibitory and stimulatory signals of FMRFamide-related peptides. Peptides 16:1181-1186.

Wang Z, Lange AB, Orchard I (1995b) Coupling of a single receptor to two different $G$ proteins in the signal transduction of FMRFamiderelated peptides. Biochem Biophys Res Commun 212:531-538.

Weimann JM, Marder E, Evans B, Calabrese RL (1993) The effects of SDRNFLRFamide and TNRNFLRFamide on the motor patterns of the stomatogastric ganglion of the crab Cancer borealis. J Exp Biol 181:1-26.

Wilmot CM, Thornton JM (1988) Analysis and prediction of the different types of $\beta$-turn in proteins. J Mol Biol 203:221-232.

Wilson R, Ainscough R, Anderson K, Baynes C, Berks M, Bonfield J, Burton J, Connell M, Copsey T, Cooper J (1994) $2.2 \mathrm{Mb}$ of contiguous nucleotide sequence from chromosome III of $C$. elegans. Nature 368:32-38.

Wishart DS, Sykes BD (1994) Chemical shifts as a tool for structure determination. Methods Enzymol 239:363-392.

Wüthrich K (1986) NMR of proteins and nucleic acids. New York: Wiley.

Yang H-Y, Fratta W, Majane EA, Costa E (1985) Isolation, sequencing, synthesis, and pharmacological characterization of two brain neuropeptides that modulate the action of morphine. Proc Natl Acad Sci USA 82:7757-7761.

Yao J, Dyson HJ, Wright PE (1994) Three-dimensional structure of a type VI turn in a linear peptide in water solution: evidence for stacking of aromatic rings as a major stabilizing factor. J Mol Biol 243:754-766.

Yeagle PL, Alderfer JL, Salloum AC, Ali L, Albert AD (1997) The first and second cytoplasmic loops of the G-protein receptor, rhodopsin, independently form $\beta$-turns. Biochemistry 36:3864-3869. 